\title{
Disappearing States: Harnessing International Law to Preserve Cultures and Society
}

\author{
Gregory E. Wannier \& Michael B. Gerrard
}

\section{Abstract}

Climate change poses a particular risk to small island nations with territories lying mostly or entirely only metres above sea level today. If, as scientists believe will happen, rising sea levels force the entire populations of such countries to relocate, several novel legal questions will arise relating to the legal status of the national entities, as well as of their citizens. The basic legal requirements for sovereignty, which include a defined territory and population, may preclude continued recognition in the international world, although jus cogens norms may enable deterritorialised nations to fight any loss of sovereignty. If absolute sovereignty is lost, though, other quasi-state arrangements may be possible that would allow community leaders to continue to provide for scattered populations. These scattered communities would also be protected by basic human rights protections, but just how this protection would manifest itself, and particularly how such protections could be enforced against host countries, remains unclear. Steps taken within the United Nations Framework Convention on Climate Change (UNFCCC) to require preparation for displacement eventualities on an international scale may offer an avenue for resolution of these questions, however. Separate efforts to establish a new treaty providing for the rights of climate-displaced persons offer a measure of hope, although there is some debate whether such efforts are worthwhile, or whether they instead distract from the more detailed, and possibly more plausible, efforts to solidify protections within existing international systems. It is not clear how such legal questions might best be resolved, but advanced engagement on these issues will be important to preventing needless difficulties into the future. 


\section{A. Introduction}

As carbon emissions increase around the world, sea levels will continue to rise and extreme weather events will become more frequent and intense. In this climatic turmoil, there is a very real danger that a group of 22 island nations located around the world, but particularly in the western Pacific, will be lost. These territories - home to approximately seven million people ${ }^{1}-$ lie mere feet above the current ocean surface, and could become largely uninhabitable owing to inundation by the sea.

In the face of such threats, several questions arise. Some of these questions are legal in nature: What happens to a country whose territory disappears? Is it still a country? What becomes of its people? Do they retain citizenship? Where do they go, and what sort of status can or should they have in their new homes? And, of course, who pays for the inevitable relocation? Other such questions are more practical: How soon will such a transition need to take place? What can be done to put off such a day as long as possible? And how can the entire process be organised and structured to limit, at least to the extent that such a limitation is possible, the inevitable upheaval in these communities? These questions are as complicated as they are numerous, and no article, or even book, could possibly resolve all of them. As such, this article limits itself largely to the first set of (largely legal) questions listed above, although it does also discuss the available facts about sea-level rise to set out the timeline over which the legal eventualities listed here may take place and when protective measures can no longer wait.

At a minimum, as this article discusses, threatened nations must prepare themselves legally for a future without habitable territory, and there are several important diplomatic and political steps each nation could pursue to strengthen its legal standing into the future. To the extent possible, this article (which was inspired by a book on the same topic that addresses many of the issues below in far greater detail) examines current legal instrumentalities and then explains how they can be utilised.

1 Washington Times (2009). 


\section{B. Scientific Summary: Rising Sea Levels}

The scientific consensus is that sea levels will rise largely as a result of increasing greenhouse gas concentrations. Steps that mankind takes now to moderate greenhouse gas emissions may eventually reduce the rate of sealevel rise, but any such steps will not stop it. ${ }^{2}$ The height of such a rise is unknown, however.

The Intergovernmental Panel on Climate Change (IPCC) in 2007 projected that sea levels will rise, largely as a result of glacial melt and thermal expansion of the oceans, by between 18 and $60 \mathrm{~cm}$ by $2100 .{ }^{3}$ But this estimate does not include the likelihood that discharge of glaciers into the sea could accelerate as glacier sheets deteriorate. ${ }^{4}$ Another estimate, which focuses on the statistical relation between temperature and sea level and extends that relationship out to periods of higher temperature, has estimated sea-level rise by 2100 (based on temperature predictions for that year) at between 75 and $190 \mathrm{~cm} .{ }^{5}$ Yet other estimates, focusing entirely on sea-level rise due to glacial loss in the arctic regions, have found that those alone could cause between 30 and $120 \mathrm{~cm}$ of sea-level rise by the end of the century. ${ }^{6}$

These various estimates rely on different technologies and different assumptions about the world. However, one team's analysis of the results, synthesising the various estimates and combining them to approximate academic consensus, has determined that "a lower bound of $1 \mathrm{~m}$ for sea level rise [by 2100] seems unavoidable" and "there may be an increase of [up to] 2 m". ${ }^{7}$

It should also be remembered that sea-level change is inherently unequal; that is, certain areas of the world will experience more extreme sea-level rise than other areas. This is partly because the input into the ocean of water from glaciers in different parts of the world will inevitably disrupt ocean currents, and the current system of currents pushes water levels higher in some areas than others. ${ }^{8}$ For instance, from 1993 to 2007 , sea-level rise was greatest in the western Pacific and central Indian Oceans, and near Greenland and

2 IPCC (2007).

3 Meehl et al. (2007:820f.).

4 Carr et al. (2013).

5 Vermeer \& Rahmstorf (2009:21530).

6 Pfeffer et al. (2008:1341).

7 Carr et al. (2013).

8 Milne et al. (2009:472). 
Antarctica. ${ }^{9}$ Sea level can also be affected more dramatically over limited periods of time by regional weather patterns such as the El Niño Southern Oscillation (ENSO), which undermines normal trade winds that push water east, away from the western Pacific. ${ }^{10}$

Threatened nations have been and will continue to be subject to storm systems as well, which can temporarily raise sea levels with sometimes catastrophic results. These storms will inflict more severe damage as sea levels rise because the altitude of these nations above sea level will diminish. In addition to this, numerous studies have indicated that climate change, and more specifically the warming of the world's oceans, is likely to result in more powerful and more numerous storms around the world, including more variable precipitation patterns. ${ }^{11}$

In the context of threatened island nations, these are dire projections, particularly for an island with a maximum elevation of two metres or less above the mean-high-tide sea level. If one adds in regional variation, which anticipates that sea levels will rise higher in the western Pacific and Indian Oceans than in other parts of the globe, the projected elevation gains increase. Individual islands could find themselves semi-permanently overtopped in a matter of decades; and even before that occurs, a single ENSO event or other large storm could overtop these islands and cause saltwater inundation that poses a threat to local plant life and freshwater supplies.

The effect of these changes on individual island nations will vary broadly: islands will face greater or lesser inundation, depending on their unique geography; and greater or lesser devastation, depending on the situation of their populations. ${ }^{12}$ But, at the very least, as a result of these anticipated environmental changes, widespread migration is expected from the populations of these threatened island nations to nearby larger islands and, eventually, to more distant continents. ${ }^{13}$ This migration will be large from a regional perspective, as the populations of entire countries may be forced to leave. One recent estimate suggests that regional migration alone from four of the most threatened island nations in the western Pacific will constitute around 500,000 people. ${ }^{14}$ This number is approximately a third of the total

9 Carr et al. (2013); Meehl et al. (2007:813).

10 Carr et al. (2013).

11 Mimura et al. (2007: 691); Nurse et al. (2007:852); Hay et al. (2003).

12 Mimura et al. (2007:690-694).

13 Gillespie (2004:113).

14 Wyman (2013). 
combined annual migration into the United States, Australia and New Zealand, three of the most likely eventual homes for these populations, ${ }^{15}$ but it is a drop in the bucket when compared to the approximately 200 million climate change migrants expected worldwide by the year 2050, according to one prominent estimate. ${ }^{16}$ But given these nations' unique circumstances (the potential loss of the entirety of their territory), it is appropriate to think of these populations as distinct, and their smaller size may ultimately ease efforts to forge a tailored long-term solution for the region.

\section{The Question of Sovereignty}

One of the basic legal questions that could arise from the effective disappearance of threatened island nations is about what happens to the status of the countries themselves. ${ }^{17}$ This is a particularly sensitive question in the context of many of the countries likely to be so affected, because many, if not most, of these islands have long histories under external rule, and have only recently achieved independence. ${ }^{18}$ However, even without such historical implications, sovereignty in the international system provides numerous practical benefits that these populations cannot afford to lose. It allows countries to establish systems of law and government, to levy taxes, and to incur debts to finance public projects. ${ }^{19}$ Membership of the United Nations (UN) also "gives nations the ability to negotiate, secure funding for their people, vote for measures that benefit them in the short and long term, participate in international forums, and otherwise acquire and exert political influence in the international community". ${ }^{20}$ All these privileges and powers may well be the difference between a structured transition that maintains these people's cultural and societal rights, and an uncoordinated exodus re-

15 (ibid.).

16 Myers (2005).

17 See Menefee (1991:181).

18 United Nations membership was attained by the Republic of the Maldives in 1965; the Republic of Vanuatu in 1981; the Republic of the Marshall Islands and the Federated States of Micronesia in 1991; the Republic of Palau in 1994; the Republic of Kiribati and the Republic of Nauru in 1999; and Tuvalu in 2000. United Nations, Member States of the United Nations, http:/www.un.org/en/members/index.shtml, last accessed 18 March 2013.

19 Wannier \& Gerrard (2013).

20 (ibid.). 
sulting in a powerless diaspora settling on the margins of local communities around the world.

\section{Maintaining Sovereignty}

Turning first to the question of sovereignty, international law has generally accepted that a modern state is defined by four distinct characteristics: (1) a defined territory; (2) a permanent population; (3) a functioning government; and (4) independence. ${ }^{21}$ For each of these requirements there are well-established precedents on what does or does not qualify.

A defined territory need not be any particular size, but land that is below the water at high tide cannot qualify as territory, ${ }^{22}$ even where a structure has been built on such land that does remain above the ocean at high tide. ${ }^{23}$ There also may be habitability requirements. Although even an uninhabited rocky outcrop may be considered as land under the United Nations Convention on the Law of the Sea (LOSC), ${ }^{24}$ land under a "functional interpretation" is necessary, but not sufficient, for satisfying the "defined territory" requirement: "[w]hat is at issue here is the distinction between the acquisition of territory by existing States and the territory necessary for a State to ... survive." ${ }^{25}$

In such a situation, the critical goal then becomes the preservation of an island territory capable of sustaining human life and society as it has developed. Fortunately, an already existing island may be artificially protected to maintain habitability and thereby maintain its territorial status under LOSC Article 60(8). ${ }^{26}$ This tool has limits, however: it may not be used to

21 Grote Stoutenburg (2013).

22 Case Concerning Maritime Delimitation and Territorial Questions between Qatar and Bahrain (Qatar v Bahrain) (Merits), Judgment, International Court of Justice, 16 March 2001, I.C.J. Rep. 2001, 40, at 100ff.

23 See Lavalle (2004:53).

24 United Nations Convention on the Law of the Sea, 10 December 1982, entered into force 16 November, 1994, 1833 United Nations Treaty Collection 397 (hereinafter LOSC).

25 Grote Stoutenburg (2013).

26 Symmons (1995:3). 
create newly habitable territory (at least under the current interpretation of the law). ${ }^{27}$

The second requirement for statehood is a stable and permanent population. The legal question that requires resolution here is: at what point does a population cease to be permanent? There does not appear to be a strict numeric requirement: the UN has recognised a group of as few as fifty people as a "permanent population" with the rights to a sovereign state, and the same number has been said to qualify an island as inhabited under the LOSC. ${ }^{28}$ There are, however, also qualitative requirements: one German court, for instance, held that such a permanent population must maintain basic infrastructure for its members, as well as demonstrate an intention to live together as a community. ${ }^{29}$ These qualitative requirements would however be unlikely to hinder any effort by a remaining population to categorise itself as permanent, as the communities most at risk have a long history of communal living, "as a community", and should be expected to continue that tradition. As scholars have noted, any such remaining community could then "anchor" the legal status of a nation for a larger population. ${ }^{30}$

The third requirement for statehood under the traditional definition is some form of working government. To fulfil this requirement, governments must exert some degree of control over the defined territory and permanent population. This is not an overly demanding requirement, however: the general rule vis-à-vis a functioning government is that the right to exert control is more important than the actual realisation of control over the land. ${ }^{31}$ In this situation, the threatened island nations currently have the unquestioned right to exert control over their territories. To avoid a collapse of governmental structures, central authorities might plan in advance for an eventual exodus from the islands, and they may find it easier to exert some control over the remaining land if some nucleus of people remains to provide gov-

27 This article does not address in detail the variety of physical innovations that may be harnessed to preserve habitability, but the options are numerous and include construction of sea walls, innovative housing arrangements, and lifestyle changes designed for greater interaction with the ocean.

28 United Nations General Assembly Resolution 2869 (XXVI), 20 December 1971; Van Dyke \& Brooks (1983:286).

29 Grote Stoutenburg (2013), quoting Verwaltungsgericht Köln, 3 May 1978, Case No. 9 K 2565/77, Deutsches Verwaltungsblatt 510, at $511 \mathrm{ff}$.

30 Grote Stoutenburg (2013).

31 Crawford (2006:57). This again attests to the influence of considerations of legality on the definition of statehood. 
ernment services to the communities that may attempt to remain for as long as possible. Thus, this factor increases the importance to island nations of preparing for future eventualities so that their societal structure does not deteriorate; but apart from such a disaster the requirement for a working government is not likely to present a significant burden to recognition as a continuing government in international law. To the contrary, the governing structure is likely to outlast the existence of a defined territory and permanent population over which to govern.

The final traditional prerequisite for sovereignty in international law is independence, which has also been described as the "capacity to enter into relations with the other States". ${ }^{32}$ Today, the new criterion that this requirement is said to add is legal independence from the authority of another sovereign entity. There has been some discussion as to whether states must meet this last requirement, and, if so, how it should be met, with some academics making the point that once an island nation becomes wholly dependent on outside aid it might lose its de facto independence and therefore no longer qualify as independent. ${ }^{33}$ The more common understanding, however, is that de jure independence (i.e. a refusal to subject one's laws to those of another state) would qualify and allow a threatened nation to satisfy this requirement. A difficulty with such an arrangement, of course, is that the continued independence of such a governing body would depend on the goodwill of a host country where such a governing body is located. In practice, it seems possible that the "independence" inquiry may become conflated with the entire sovereignty question, rather than be seen as just one of four discrete requirements, because the same manipulations of legal understanding that would allow a displaced nation to continue its "independence" could just as easily skip the preceding analysis and also continue that nation's "sovereignty".

As the analysis above hopefully makes clear, the legal status of nations whose populations have mostly or entirely fled remains in serious doubt under the traditional definition of sovereignty - even considering the ability of law and legal definitions to evolve over time. It seems likely that if a small island nation is able to maintain even a basic population presence on an island and use that as the centre for its governance, the legal status of the country would not be in question. The situation for a fully displaced people is much

321933 Montevideo Convention on the Rights and Duties of States.

33 Grote Stoutenburg (2013). 
more difficult, though. There is some precedent for continued recognition of a government-in-exile from World War I, where organisations such as the Czechoslovak National Council and the Polish National Committee were recognised as representing their territories under German rule. ${ }^{34}$ But such arrangements were based on the illegitimate occupation of territory by another country; while here, the 'illegitimate occupier' is the ocean, and so it may be difficult to draw any useful parallel to those situations successfully.

\section{Alternatives to Complete Sovereignty}

If threatened island nations are ultimately unable to demonstrate their status as sovereign entities and retain full sovereignty, a series of unappealing alternatives awaits. The starkest possibility is the loss of sovereignty without a replacement governing structure of any type - which would leave a lost country's former citizens without any of the traditional protections of nationality. This is certainly a possibility, but the governing structures in these states are well aware of the problem, and have discussed possible outcomes among themselves and at conferences around the world. ${ }^{35}$ These communities also maintain an active political and diplomatic presence in the UN and elsewhere through organisations like the Association of Small Island States (AOSIS).

On the spectrum between this outcome and full sovereignty, scholars have suggested several alternatives to formal sovereignty in its traditional sense in the international system. Many of these ideas come from historical examples of deterritorialised state-like entities, including the following: (1) countries without a territory; (2) governments in exile from their claimed territory; (3) governments unable to exert control over their territory; and (4) economic entities with quasi-governmental roles. ${ }^{36}$

One commonly discussed example of a country without a territory is the Sovereign Military Order of Malta, which enjoys quasi-sovereign status and is granted observer rights at many major international forums despite not

34 (ibid.).

35 See e.g. Conference on Threatened Island Nations: Legal Implications of a Changing Climate, Columbia Law School, held in New York, NY, May 23-25 2011, see https:/ /www.law.columbia.edu/null/download?\&exclusive=filemgr.download\&file_id=5 844, last accessed 11 May 2013.

36 Burkett (2013). 
having any defined territory. ${ }^{37}$ Another is the Holy See, which is recognised as a sovereign subject even though it does not possess some of the traditional indices of statehood, such as a permanent population and independent territory. ${ }^{38}$ The Holy See is a particularly useful example, because from 1870 to 1929 it did not even officially have ownership of the land that the Vatican City now occupies, ${ }^{39}$ and yet it continued active diplomatic relations with most states, and participated (as it does today) in international agreements. ${ }^{40}$

There are several examples of governments in exile that continue to participate in international discussions today. Perhaps the most well known is the Palestinian Territory, which has been an observer at the UN for many years, may participate in debates there, and was upgraded to "nonmember observer state" on November 29, 2012. ${ }^{41}$ The international community also recognises indigenous nations whose territories have been claimed by existing states, such as the Maori and Tibetans, as integral members of the international debate. ${ }^{42}$ Indeed, history is "replete with examples" of governments operating in the territory of other states. ${ }^{43}$ The limitation here, of course, is that such situations of exiled governments are generally considered to be responses to temporary and exceptional circumstances. ${ }^{44}$

Examples of continued recognition of governments unable to control their own territory (or so-called "failed states") abound in international law. ${ }^{45}$ Most notably in recent years, Somalia has continued to enjoy international recognition despite failing to exert control over its territory far beyond its capital, Mogadishu, and despite the presence of an insular separate governing body, Somaliland, that exerts control over its claimed territory and declared independence in $1991 .{ }^{46}$

And finally, the best known example of an economic entity gaining recognition in the UN is the European Union (EU), which has no set territory or population of its own, but rather imposes authority on top of already ex-

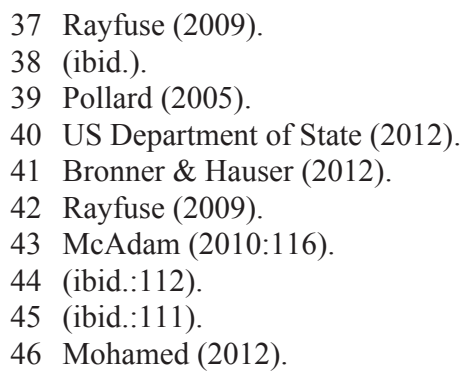


isting nations across Europe. In spite of this unusual legal status, the EU offers separate citizenship, which grants additional and tangible benefits to those citizens beyond those granted by their country citizenship..$^{47}$ The same is true for Taiwan, which is no longer recognised in the UN as a separate country, but enjoys so-called "functional sovereignty" in the international sphere, and particularly in international economic affairs, although it is not recognised as a state. ${ }^{48}$

Each of these different arrangements offers interesting alternatives to full and complete sovereignty, although each is subject to its own constraints. For instance, of the group the only entities that enjoy full diplomatic status (including the right to vote on resolutions in the United Nations) are the various failed states that still maintain a territory over which they ostensibly rule. The Holy See and entities such as the EU, Palestine and Taiwan do provide useful examples of quasi-state territories actively participating in debates and discussion in international forums, and these are perhaps viable fallback positions should depopulated island nations fail to maintain complete sovereignty, but this still falls short of full recognition.

There are also various examples of quasi-independent status within countries, including in Native American reservations in the United States, where tribal governments are seen as somewhat independent, but not quite as foreign states and as such are unable to engage in foreign diplomacy. ${ }^{49}$ According to United States law, tribal governments are not considered parties to the United States Constitution and therefore do not even enjoy constitutional protections accorded therein. ${ }^{50}$ However, Congress continues to have "plenary" power over these nations, and they are banned from independent participation in international diplomatic efforts. ${ }^{51}$ This alternative, and others like it, are unlikely to provide the voice and independence that depopulated island nations would seek in any new home, and represent a less appealing fallback position for these nations.

But existing structures need not be the only source of ideas for the disposition of the future of threatened island nations; and one academic in particular, Maxine Burkett, suggests an innovative new structure: the "deterri-

47 Rayfuse (2009:11).

48 Burkett (2013).

49 Cherokee Nation v Georgia, 30 U.S. 1 (1831); Indian Civil Rights Act of 1968.

50 Indian Civil Rights Act of 1968; Talton v Maves, 163 U.S. 376 (1896).

51 Lone Wolf v Hitchcock, 187 U.S. 553 (1903). 
torialised state". ${ }^{52}$ This model is based on a political trusteeship system, whereby a sitting government would manage the affairs of the state and of its diaspora from afar. ${ }^{53}$ Such an arrangement might be similar to the continued management of maritime zones (discussed below), but "greater emphasis would be placed on preserving all other elements of the nation-state that should endure extraterritorially - key among them including the persistence of culture, connections among its people, and the security and wellbeing of its citizens". ${ }^{54}$ Members of the ex-situ government would be considered political trustees, and would be responsible for administering the assets of the deterritorialised state for the benefit of its people. Such arrangements would be similar to such trusteeship arrangements that were organised by the League of Nations and the UN for postcolonial transitions around the world in the 20th century, ${ }^{55}$ and could even follow many of the same goals of the original trusteeships (i.e. to "promote the advancement of detrimentally affected peoples consistent with their freely expressed wishes" ${ }^{\prime 56}$ ), except that the diaspora would select its own trustees who would have absolute political independence. ${ }^{57}$ In practice, the UN might offer its services to facilitate long-term governance, and might provide a secretariat to focus UN support for deterritorialised states, but would not govern these states. The final advantage of such an arrangement is that such a designation of nationality would allow the nation ex-situ to exercise jurisdiction over its citizens. ${ }^{58}$ Such jurisdiction could be in addition to diaspora members' citizenship in their home state - in a situation akin to that enjoyed by citizens of the EU. At the same time, the ex-situ nation will advocate on behalf of its citizens, particularly in circumstances in which they are less well off because of resettlement. ${ }^{59}$

52 Burkett (2013).

53 (ibid.).

54 (ibid.).

55 Perritt (2003:387-389).

56 UN Charter, Chapter XII, Articles 76 and 78.

57 Burkett (2013). This would be in direct contrast to the original trustee systems, which allowed for extensive UN oversight. UN Charter Chapter XIII, Articles 86 and 87.

58 Blackman (1998:1149).

59 This scenario is not far-fetched. See Kolmannskog (2009:12), explaining that involuntary relocation and resettlement rarely lead to improvements in the quality of life of those moved; therefore, moving communities in anticipation of climate change may precipitate vulnerability more than it avoids it. This decline in livelihood due 
Burkett suggests an interesting organisational structure for a state-like entity that might result from the depopulation of existing island nations, and this suggestion merits attention no matter what the final status of these nations is. But the international participation and voting rights of the nation ex-situ itself will still depend on international recognition. Without such recognition, these deterritorialised states would join the body of pseudo- and partial states on the outskirts of UN decision-making.

\section{Fighting any Potential Loss of Sovereignty}

Although the quasi-state entities discussed above would be preferable to complete loss of nationality, continued sovereignty presumably remains the ultimate goal for the citizens of these nations. As an alternative to fighting to redefine the traditional understanding of sovereignty, or accepting a second-class status as a semi-state, there may be some avenue for maintaining full sovereignty using jus cogens norms, as has been explored particularly thoroughly by Jenny Grote-Stoutenburg. Under this theory, events leading to the disappearance of states (i.e. the loss of territory) could be ignored where they result from "a violation of a fundamental norm of the international legal order" (just cogens norm). ${ }^{60}$ Article 53 of the Vienna Convention on the Law of Treaties defines jus cogens norms, noting that they must be "accepted and recognized by the international community of States as a whole as a norm from which no derogation is permitted and which can be modified only by a subsequent norm of general international law having the same character". ${ }^{61}$ More importantly, a treaty is void if it is found to be in conflict with a jus cogens norm. ${ }^{62}$

The concept that actions are legally void to the extent that the conflict with a jus cogens norm has gained recognition outside the context of treaties, including in the International Law Commission's Draft Articles on the Re-

to climate-related relocation and resettlement may have precedent. See Vainerere (2009).

60 Grote Stoutenburg (2013).

61 Vienna Convention on the Law of Treaties, 23 May 1969, entered into force 27 January 1980, 1155 United Nations Treaty Collection 331.

62 (ibid.). 
sponsibility of States for Internationally Wrongful Acts (DASR) of $2001 .{ }^{63}$ Under the DASR, a situation that results from a country violating a jus cogens norm may not be recognised as lawful by other states. ${ }^{64}$ This norm has been used as a basis for refusing to recognise shifts in sovereignty in several situations, including Japanese incursions into China in 1931; Turkey's attempt to establish the Turkish Republic of Northern Cyprus in 1983; Germany's annexation of Austria, Poland, Czechoslovakia and the Baltic States from 1936 to 1940; and most recently Iraq's annexation of Kuwait in $1990 .{ }^{65}$ In each of these situations, unsanctioned military aggression was the basis for application of the jus cogens norms; but there is nothing explicitly prohibiting application of these norms in other contexts.

For threatened island nations, the perpetuation of arguably unlawful emissions, which worsen global climate change, offers an opportunity to apply jus cogens norms. According to Article 2 of the DASR, a "wrongful act" consists of two elements: first, that a state takes some action that manifests in international law; and second, that such action breaches such a state's international obligations. ${ }^{66}$ If applied to the climate emissions context, the relevant action would be the failure of the state to regulate the emissions of activities within its borders. The second would depend on the nature of the obligation of each state. Relevant to this inquiry, many (though not all) states have undertaken obligations through the UNFCCC to reduce their emissions, ${ }^{67}$ and have even committed themselves to numeric obligations under the Kyoto Protocol. ${ }^{68}$ Without going into the details of these agreements (as other articles in this volume do), it is also clear at this point that the Kyoto Protocol failed, during its first commitment period of 2008

63 United Nations General Assembly Official Records, International Law Commission, Draft Articles on Responsibility of States for Internationally Wrongful Acts, with Commentaries (DASR), 56th Session Supp. No. 10, 43 (2001).

64 Article 41(2) DASR.

65 Grote Stoutenburg (2013).

66 Article 2 DASR; see Article 4 DASR, "The conduct of any State organ shall be considered an act of that State under international law, whether the organ exercises legislative, executive, judicial or any other functions, whatever position it holds in the organization of the State, and whatever its character as an organ of the central Government or of a territorial unit of the State.".

67 United Nations Framework Convention on Climate Change, 9 May 1992, entered into force 21 March 1994, 1771 United Nations Treaty Collection 107.

68 Kyoto Protocol to the United Nations Framework Convention on Climate Change, 10 December 1997, entered into force 16 February 2005, (1998) 37 International Legal Materials 32 . 
2012 , to achieve a reduction in greenhouse gas emissions. But the extent to which this involved any violation of law by nations that signed the Kyoto Protocol is debatable. Among the largest emitting nations, one (the United States) did not ratify the Kyoto Protocol; others withdrew from it (Canada, Japan, Russia); others (such as China and India) did not commit themselves to any emissions reductions obligations. The number of nations that fulfilled and even significantly exceeded their Kyoto Protocol obligations and still acknowledge their obligations is small, and few of them have large economies. ${ }^{69}$ It would be difficult or impossible to demonstrate that the emissions from these few countries in excess of their international commitments contributed in a major way to the plight of the island nations.

Assuming there are countries that did in fact violate their international obligations to some significant degree, island nations seeking to maintain their status as nations would still need to establish violation of jus cogens norms. The most likely jus cogens norms to be affected would be the right to self-determination, to sovereignty over one's resources and territory, and (on an individualised basis) to nationality within a country. Two related International Human Rights Covenants passed in 1966 provide explicitly for the right to self-determination, including determination of political status, and of social and economic development. ${ }^{70}$ They also provide that communities should be allowed to utilise their own natural resources as they choose. ${ }^{71}$ And the Universal Declaration on Human Rights of 1948 provides individuals with the right to nationality. ${ }^{72}$ Here, the importance of these fundamental rights, and the degree to which they have been lost, are clear: people losing their homeland and their community because of the failure of others to reduce their own pollution would almost certainly qualify as a jus cogens norm.

In summary, it seems clear that the path to full sovereignty, both through traditional definitions and through application of jus cogens norms remains uncertain from a purely legal perspective. However, multiple observers have noted that considerations of equity and acceptance of their moral responsi-

69 IEA (2012:13 Table 1). Australia is the largest economy with such an exceedance.

70 International Covenant on Civil and Political Rights, 19 December 1966, entered into force 23 March 1976, 999 United Nations Treaty Collection 171; International Covenant on Economic, Social and Cultural Rights, 16 December 1966, entered into force 3 January 1976, 993 United Nations Treaty Collection 3.

71 (ibid.).

72 United Nations General Assembly Resolution 217 (III) A, 10 December 1948. 
bility can and should prompt states in the developed world to continue recognising depopulated island nations even after their territories become uninhabitable, particularly where several legal hooks remain that would justify such treatment. For several reasons, outlined above and below, this would be preferable to recognition of a quasi-state status, which would provide such nations very little power to protect their diasporas.

\section{Preserving Maritime Boundaries}

One of the most important legal privileges afforded to nations that would need to be resolved in the context of threatened island nations is the right to maritime zones adjacent to land territories, and their associated fishing and subsea minerals rights. To some extent, resolution of this legal question will be tied to resolution of the statehood question, discussed above. Traditionally, only habitable islands may form the basis for large marine territories. However, marine territories are also subject to an entirely separate body of law, anchored by the LOSC and related treaties and agreements.

The current regime dates back to 1982, when the major countries of the world first met to discuss norms of maritime diplomacy, and began to negotiate what has since become the LOSC..$^{73}$ The LOSC officially came into effect on November 16, 1994, and has been ratified by 161 nations. ${ }^{74}$ The list of ratifying nations notably lacks the United States (although it recognises large swathes of the treaty as binding customary international law). ${ }^{75}$ As structured, the LOSC establishes four distinct "maritime zones" in the oceans: internal waters, territorial waters, the contiguous zone, and the exclusive economic zone (EEZ), with the high seas constituting the remainder of the ocean. ${ }^{76}$ Each of these zones is determined on the basis of a given coastal state's "baseline", defined as the low-water mark of the coast. ${ }^{77}$ States have absolute control over internal waters and over the territorial sea extending 12 nautical miles from the baseline. ${ }^{78}$ They may also exert control over the contiguous zone to the extent necessary to protect their sovereign

73 See generally LOSC.

74 See Status of LOSC, United Nations Treaty Collection.

75 Holmes (2008:332).

76 See Articles 46-54 LOSC.

77 Article 5 LOSC.

78 Articles 2, 3 and 8 LOSC. 
territory. ${ }^{79}$ But by far the largest zone associated with a state, and the one which therefore grants the greatest benefits to a potentially displaced island population, is the EEZ, which generally extends 200 nautical miles from the baseline. ${ }^{80}$ Within this zone, a state enjoys sovereignty over all living and nonliving resources in the water, on the seabed, and in the subsoil. ${ }^{81}$ Interestingly, states may also establish artificial islands within their EEZ, although the establishment of such islands does not create a new basis for an EEZ. ${ }^{82}$ And finally, states independently are granted jurisdiction over the seabed and subsoil resources of their continental shelves (although not the water above those shelves) under a separate section of the LOSC. ${ }^{83}$ This control extends to the end of the continental shelf, even if the shelf itself extends beyond 200 nautical miles from the baseline. ${ }^{84}$

The distinction between the EEZ and the continental shelf is not insignificant: most notably the LOSC offers avenues to secure continental shelf jurisdiction permanently, namely by allowing a state to provide the UN secretary-general with a geographic delimitation of the state's proposed territory (even if it does not adhere to the underlying physical topography). ${ }^{85}$ The obvious implication of this provision is that states fearing a loss of territory can take prior steps to claim their continental shelves and thereby retain them in perpetuity. ${ }^{86}$ This conflicts directly with the situation for EEZs, which cannot ever become permanent - at least not under a plain reading of the LOSC. ${ }^{87}$ Thus, the norm under the LOSC will be that as island nations lose land territory, causing their baseline to shrink, their presumptive EEZ will similarly retreat and shrink (the term used for this phenomenon is "ambulatory baselines"). This means that states would not be able to maintain their fishing rights around submerged islands (and the associated revenues), but they could maintain the rights to subsea minerals.

In the face of such an eventuality, there are several steps, both legal and physical, that threatened island nations might take to preserve their marine territories. The physical innovations are probably more straightforward, and

79 Article 33 LOSC.

80 Article 57 LOSC.

81 Article 56 LOSC.

82 Articles 56 and 60 LOSC.

83 Articles 76 and 77 LOSC.

84 Articles 1, 76 and 77 LOSC.

85 Article 76 LOSC; Soons (1990:216f.).

86 Soons (1990:216f.).

87 Articles 76-79 LOSC. 
centre around the way LOSC determines the boundaries of the various marine zones. As noted above, the international community has accepted the possibility that coastal states may buttress current habitable islands and therefore maintain the "habitability" designation: the same holds true under the LOSC. ${ }^{88}$ This strategy is not without its risks - numerous studies have demonstrated the difficulties associated with artificially altering natural mineral flows on an isolated island through the construction of hard structures, including unanticipated erosion elsewhere on the same island ${ }^{89}$ - but may also be applied to preserve the outer-bound baselines defining marine territories under the LOSC. In one of the better-known examples of such a strategy, Japan has employed just such a strategy to maintain the 40,000 potential square nautical miles surrounding a tiny island, Okinotorishima, in the far south of Japan. ${ }^{90}$ This has not been without controversy, and indeed both China and the Republic of Korea have filed official protests. ${ }^{91}$ Island nations facing the loss of their homeland would be in a position to respond to similar protests by focusing particularly on the equities involved. In fact, the equities in favour of such nations are so strong that some scholars have suggested that artificial or even floating islands could provide a new anchor for both statehood and marine territories. ${ }^{92}$ Although this would seem to conflict directly with the rules in the LOSC against granting artificial structures any recognition, ${ }^{93}$ such nations might justifiably present such installations as mere preservation projects of territory that will otherwise disappear in its entirety.

A less drastic and controversial option exists for islands that stand to lose large chunks of their territories without losing their entire territory: the maintenance of island basepoints. Because islands are by their nature irregular in shape, certain points on the land will provide the furthest "reach" for purposes of calculating marine territory, with large swathes of islands having no effect on the ultimate calculation of the EEZ. Thus, to the extent that they bulwark parts of their territory that are subject to submergence, island nations might limit territorial loss by focusing their preservation efforts on such "reach" points, which are usually the tips of peninsulas or other extreme

88 Soons (1990:222).

89 Schofield \& Freestone (2013).

90 Song (2009:148).

91 Schofield \& Freestone (2013).

92 (ibid.).

93 Article 60(8) LOSC. 
points in island geography. Such efforts cannot themselves prevent the unfortunate loss of land territory, but could preserve valuable swathes of EEZs, which can be rented out for fishing rights, as well as continental shelves that can be rented out for mineral access and provide a source of income to these island populations.

Although physical efforts to maintain targeted areas may provide a bulwark against severe declines in land and sea territories, perhaps the most effective solutions for maintaining marine territories are exclusively legal in nature. In addition to claiming continental shelves immediately, threatened island nations may call for certain interpretations of LOSC rules that freeze baselines regardless of future changes in land territory. As one such example, Article 5 of the LOSC provides that "the normal baseline for measuring the breadth of the territorial sea is the low-water line along the coast as marked on large-scale charts officially recognized by the coastal State". ${ }^{44}$ Focusing on the latter part of that definition, several scholars have contemplated that once baselines are established against a present coastline, there is no requirement that those countries redefine their baselines even if the coasts recede. In effect, then: ${ }^{95}$

the practical effect of marking the low-water line on large-scale charts officially recognized by the coastal State may be to "fix" that baseline as against coastal regression and the claims of other States, at least until such time as new charts are produced.

The difficulty, of course, is that navigation charts are used for more than baseline delimitation; they are used to navigate, and so refusal to update those charts could have disastrous results. This could provide pressure against states' refusals to update their charts.

An alternative legal innovation focuses on Article 7(2) of the LOSC, which allows the use of "straight baselines" between points "along the furthest seaward extent of the low water line" in certain circumstances. ${ }^{96}$ This approach is allowed where "because of a delta and other natural conditions the coastline is highly unstable", ${ }^{97}$ which test would seem to definitionally exclude island nations from utilising this approach, since they are without a delta. However, here again scholars have long suggested that a round of

94 Article 5 LOSC.

95 Rayfuse (2013); see Kapoor \& Kerr (1986).

96 Article 7(2) LOSC.

97 (ibid.). 
reinterpretation of these requirements, particularly focusing on the equities of climate change and rising seas, could bring island nations within the ambit of the Article on the basis of their unstable coastlines resulting from "natural conditions". 98 Another provision such nations could use is Article 47 of the LOSC, which allows archipelagic states to use straight baselines that connect islands together as one "baseline territory". ${ }^{99}$ This is technically only allowed for countries in certain circumstances (land-to-water ratio below 9 to 1, no straight lines longer than 125 nautical miles, and $97 \%$ of such lines shorter than 100 nautical miles), ${ }^{100}$ but again the principle of equity might compel other countries to allow threatened island nations to expand use of this Article to their situation. As a final note here, if a straight baseline redefinition approach is allowed under Article 7 or Article 47, the strategy of maintaining bulwarks along the extreme points of land territories (discussed above) will become even more important.

In their favour, marine territory claims of island states will be granted a "presumption of permanence" once they are declared and publicised in the international community; this is an argument for immediate action in preference to a delay of any sort. ${ }^{101}$ Examples already abound of other nations, such as Australia, ${ }^{102}$ defining their baselines accordingly, so such action would not be unprecedented.

In addition to options utilising the existing text of the LOSC, there are of course several other ways for threatened island nations to attempt to secure their marine territories in perpetuity. Perhaps the most straightforward method would be to call for an amendment of LOSC that would set current baselines in perpetuity. There is some support for such an effort, ${ }^{103}$ but threatened island nations may find it difficult to secure such a significant amendment to what is already a controversial treaty in many ways. Legal scholars have thoroughly examined the process by which such an amendment could be achieved; but it is at least clear that efforts would be needed to overcome what is generally a "slow and unwieldy" process. ${ }^{104}$ For that reason, other scholars suggest that the LOSC process is not the best avenue

98 See e.g. Bird \& Prescott (1989).

99 Rayfuse (2013).

100 Article 47 LOSC.

101 Rayfuse (2013).

102 Seas and Submerged Lands Act 1973 (Act No. 161/1973) (Au.).

103 Rayfuse (2013); see also Jesus (2003:602).

104 Rayfuse (2013); Hayashi (2009). 
for changing the rules, and that instead an entirely new treaty should be negotiated, perhaps within the auspices of the UNFCCC. 105

Another legally simple solution, and one that focuses more on realpolitik than on traditional international law, would be to enter into bilateral treaties with other nations that are the most likely to encroach on their marine territories, and/or who could help enforce their jurisdiction over such territories against other nations. For instance a nation unable to find a traditional justification for its continued existence might seek continued recognition from a larger and more powerful country, as well as some form of bilateral aid, in return for granting that nation exclusive fishing or mineral rights within its EEZ or continental shelf. The benefit of such a strategy is limited by the degree to which the partner nation would be willing to enforce the island nation's claims (for its own benefit), and the degree to which other nations might challenge this arrangement. However, at the very least, such an arrangement would provide the partner nation with a valid, and equitably proper, justification for its actions, while giving it an incentive to provide financing to the island nation and its diaspora.

\section{E. Existing Protections for Displaced Populations}

Although the plight of nations is important, and national status and territory may be key to providing rights and a source of income for large displaced populations, the story of rising sea levels in this context is fundamentally one about people. Particularly in the small island nations discussed here, entire populations may need to be relocated somewhere else on the planet, be forced into foreign societies, struggle to maintain communities and livelihoods, and generally face severe personal and societal stresses. However, we know very little about where these populations will go, and what rights and protections they may enjoy in their new homes. It is thus important to determine what, if any, human rights protections exist for such communities, given the context of their expected resettlement. ${ }^{106}$

The short answer to this question, unfortunately, is that human rights law provides relatively little direct guidance on how human rights protections should be applied in the context of climate change. (This leaves aside, of

105 Schofield \& Freestone (2013); Freestone \& Oude Elferink (2005).

106 See generally Knox (2009). 
course, the question - discussed below - of the enforceability of even the clearest human rights obligations.) To be sure, it is clear that climate change does implicate human rights protections; this was finally recognised formally in 2008 by the UN Human Rights Council, which adopted the first resolution on human rights and climate change. ${ }^{107}$ The regime of human rights provides several areas of protection that might apply to threatened island nation populations, and indeed it is clear that climate change does implicate several human rights, but each of these areas of human rights law requires separate analysis.

The basic patchwork of human rights protections ${ }^{108}$ has been described as centring around three basic obligations: (1) to respect other nations and their people's human rights, and not to interfere with their appreciation thereof; (2) to protect people and nations against any violations of human rights that might be perpetuated by third parties; and (3) to fulfil human rights and their enjoyment in other countries. ${ }^{109}$

The obligation to respect can be seen as providing perhaps the most useful avenue for achieving human rights protections in the context of climate change. This is because the prohibition against "interfering" with the enjoyment of human rights in other nations can clearly translate to a duty to "do no harm", which in the context of climate and threatened island nations could be seen as an injunction not to contribute to climate change, or at least to help those hurt by any such contribution. ${ }^{110}$ Indeed, the "do no harm" school of liability has already shown up in the Rio Declaration and at the

107 UNHRC Res. 7/23, U.N. Doc. A/HRC/7/78, 28 March 2008, adopted by consensus.

108 For a general summary of customary international law, see Henckaerts \& DoswaldBeck (2005:299-306). See also Universal Declaration of Human Rights, General Assembly Resolution 217, United Nations General Assembly Official Records, 3rd Session, United Nations Doc. A/810 (1948).

109 McInerney-Lankford (2013).

110 This theory has also been held forth as a method for establishing liability for climate harms caused by major emitters, because it would support "a requirement that States carry out prior assessments to predict and evaluate the effects of actions that might degrade the environmental and thereby harm individuals' rights." McInerneyLankford (2013). This article does not address questions of liability, but human rights doctrine establishing duties not to harm other countries can also provide pressure on 'violating' countries to provide basic human rights to victims of their actions. 
UN Conference on the Human Environment, ${ }^{111}$ and is the basis for the determination of the International Court of Justice that states may be held responsible for human rights violations. ${ }^{12}$

The obligation to protect imposes on states the responsibility to regulate the actions of third parties (where such regulation is possible) to ensure that these parties are not violating human rights. ${ }^{113}$ Here, drawing a connection to the possible plight of displaced communities is straightforward: states are almost certainly responsible for regulating private actors in their territory to ensure that they do not violate existing human rights protections. For instance, when displaced communities arrive unbidden in another state's territory, that host state is responsible for ensuring that its own citizens and local governments honour the nation's human rights obligations to such communities. Importantly, there is a positive human rights obligation here (something that must be done), as opposed to merely a negative obligation (something that may not be done). In addition, some scholars have argued that the duty to protect "extends beyond the confines of a State's borders and ... may have extraterritorial application" to all parties within a given country's control, whether domestic or international. ${ }^{114}$

Finally, the obligation to fulfil is an explicitly positive obligation: nations must secure conditions that are conducive to full enjoyment of human rights. ${ }^{115}$ Technically, this means that states are "under an immediate obligation to take "deliberate, concrete, and targeted steps" " toward the full realisation of human rights. ${ }^{116}$ In practice, of course, states are granted leeway in the process of seeking to ensure enjoyment of human rights, because it is

111 Rio Declaration, Principle 2; United Nations Conference on the Human Environment, Stockholm, Sweden, 5-16 June 1972, Declaration of the United Nations Conference on the Human Environment, United Nations Document A/CONF. 48/14, 11 I.L.M. 1416, 16 June 1972.

112 See e.g. Armed Activities on the Territory of the Congo (DRC v Uganda), 2005 International Court of Justice 116, 220, 19 December 2005; Legal Consequences of the Construction of a Wall in Occupied Palestinian Territory, Advisory Opinion, 2004 International Court of Justice 163, 111, 9 July 2004.

113 Again here, this obligation might be used in an attempt to establish liability against nations with domestic actors emitting large quantities of greenhouse gases. McInerney-Lankford (2013). However, this obligation may also be used to impress upon such nations the importance of regulating domestic actors who might violate displaced people's human rights more directly.

114 McInerney-Lankford (2013).

115 (ibid.).

116 (ibid.), quoting CESCR General Comment No. 3. 
impossible to achieve full human-rights-compliant behaviour instantaneously. But this norm, particularly when coupled with the norm of establishing an obligation to control the actions of third parties, could be seen as imposing a certain course of activity upon nations expected to receive large communities of displaced persons.

A difficulty with all of these three norms of human rights law is that they are fundamentally unenforceable. These discussions and protections alone may place some pressure on countries to comply, but with certain limited exceptions there are precious few concrete requirements that might actually compel countries to protect human rights around the globe. ${ }^{117}$ Human rights obligations are usually realised within a country, by citizens within that country (and sometimes other visitors to that country), ${ }^{118}$ rather than against third party countries. Thus, in the context of displaced citizens of threatened island nations, they may have recourse against their own governments (which they most likely would not take), but would find it difficult to use traditional human rights protections to impose obligations on third-party countries that must take them in. That said, linking human rights and climate change also is not a worthless exercise, because (1) it brings the full weight of human rights and obligations to bear on climate and immigration decisions, imposing pressure on countries to take steps to preserve human rights; and (2) to the extent that human rights treaties establish international norms that may influence countries' behaviour (to protect, respect, and fulfil, as above), they bring climate-related bad actions within the purview of such rules. ${ }^{119}$

One possible avenue for imposing backdoor human rights liability on countries to care for displaced island communities is the body of existing international migration law. ${ }^{120}$ Whenever people migrate from one country

117 Hannum (1995-1996); see also Sosa v Alvarez-Machain, 542 U.S. 692, 734 (2004), "[T]he [Human Rights] Declaration does not of its own force impose obligations as a matter of international law." But see Filartiga v. Pena-Irala, 630 F.2d 876, 882 (2d Cir. 1980), noting that the Human Rights Declaration does impose some obligations through customary law.

118 Darrow \& Arbour (2009:470).

119 McInerney-Lankford (2013).

120 "International migration law draws together the norms governing the legal relationships between States and those between States and individuals involved in the migration process. It is an umbrella term for an area of law that has developed over time and indeed continues to develop." Klein Solomon \& Warner (2013); See International Organization for Migration, International Migration Law http://www. 
to another, they become subject to human rights protections in both their own country of nationality and the eventual host state. There is no apparent reason to treat environmental migrants differently from other migrants, so this should apply equally to island communities. Many countries have subjected themselves to honouring certain basic human rights protections, through international agreements or national laws or both, and so migrants may find themselves in a position to invoke human rights protections in host countries' court systems directly. In short, island nation communities entering into host nations may be able to use their status as migrants to bring human rights protections to bear on the treatment they receive in their new homes. ${ }^{121}$ Such improvements in treatment could include due process under the law, a greater right to self-determination, or such basic life necessities as health services and education. This remains a relatively novel concept, and merits further consideration; but it does offer a possible role for the International Organization for Migration, which, though lacking a legal protection mandate, is responsible for contributing to the protection of migrating persons. ${ }^{122}$

In addition to the general human rights protection regime, there are certain areas of international law that may provide some hope for displaced communities seeking a tool to ensure their human rights are preserved. One such possible alternative tool centres on global refugee protections. The main instrument for refugee protections in international law is the UN Human Rights Commission, which oversees the 1951 Convention relating to the Status of Refugees (1951 Convention). ${ }^{123}$ This instrument, together with its subsequent Protocol, ${ }^{124}$ provides refugees with a guarantee of "national treatment" in the provision of housing, education, and other services, which could be exceedingly useful to a displaced group of threatened island nation citizens. In the context of climate, however, numerous scholars have observed that refugee protections under the 1951 Convention alone cannot

iom.int/jahia/Jahia/international-migration-law/lang/en (last accessed 19 March 2013), for key publications and analysis on international migration law.

121 Klein Solomon \& Warner (2013).

122 United Nations High Commissioner for Refugees (2007).

123 United Nations Convention Relating to the Status of Refugees, July 28, 1951, 19 U.S.T. 6259, 189 United Nations Treaty Collection 137 (hereinafter 1951 Convention).

124 Protocol Relating to the Status of Refugees, 31 January 1967, 19 U.S.T. 6225, 606 United Nations Treaty Collection 268. 
properly apply to climate refugees. ${ }^{125}$ The 1951 Convention defines a refugee as any person who "owing to a well-founded fear of being persecuted ... is outside the country of his nationality, and is unable to ... avail himself of the protection of that country". ${ }^{126}$ This definition seems to require that $a$ refugee's country be contributing to the problem and that the violation of human rights results from persecution; and presumably neither of these situations would exist in the context of climate displacement, where the states are working hard to provide for all of their citizens. ${ }^{127}$ In fact, the UN Human Rights Commission itself has observed that climate refugees are unlikely to be covered under the original convention. ${ }^{128}$

In certain regions, it might be argued that the situation has changed; subsequent agreements in Africa and Latin America have expanded the definition of refugee from the 1951 Convention specifically to include people who have fled their home countries as a result of any disturbance to the "public order". ${ }^{129}$ Under the expanded definitions laid out in these agreements, climate-displaced persons will find it much easier to qualify as refugees. However, the agreements only apply to the regions in which they have been adopted, and so could only provide protection to climate-displaced populations to the extent that they move to one of those two regions. ${ }^{130}$

In the face of a refugee treaty that fails to cover what may well be the largest source of refugees in the next hundred years, many have called for modification of the convention, while others argue that political refugees and climate refugees are facing such different challenges that different legal regimes are needed for the two phenomena, and also that the number of climate refugees will become so large that the plight of political refugees would be superseded. Many of the expected refugee-hosting countries have expressed reluctance to extend international refugee protections further than where they are presently. ${ }^{131}$

125 McAdam \& Saul (2010); Williams (2008); Klein Solomon \& Warner (2013).

1261951 Convention.

127 Cooper (1998); Lopez (2007).

128 United Nations High Commissioner for Refugees (2009).

129 Organization of African Unity Convention Governing the Specific Aspects of Refugee Problems in Africa, 20 June 1974, 1001 United Nations Treaty Collection 45, Article I, Paragraph 2; Cartagena Declaration on Refugees (Cartagena de Indias, 22 November 1984) OAS/Ser.L./V/II.66, doc. 10, rev. 1, 190-193, Article III, Paragraph 3.

130 See Leighton (2010:6).

131 Klein Solomon \& Warner (2013). 
Finally, even if it were politically feasible to extend refugee protections to the coming masses of environmental refugees, some scholars have argued that refugee protections are insufficient for the task. Refugee protection consists of two principal elements: (1) in the host state, treatment for persons identified as refugees equivalent to national treatment (i.e. with regard to access to education, social benefits, and the like - effectively a "nondiscrimination" principle); and (2) a "non-refoulment" principle (i.e. protection from being sent back to a place of persecution). ${ }^{132}$ Both of these would be useful protections; but refugee protections are by their nature reactive, rather than proactive. Given the predictability of upcoming climate displacement, these populations would be better served by an orderly and structured evacuation plan than they would be by an unorganised scattering, followed by individually applied general refugee protections. ${ }^{133}$

One interesting recent development in the area of climate negotiations that may provide comfort to island communities hoping for international aid for their eventual transition has been detailed in particular by Michele Klein Solomon and Koko Warner, who were involved in UNFCCC negotiations leading to the addition of language considering the plight of climate-displaced persons. ${ }^{134}$ At the $16^{\text {th }}$ Conference of the Parties to the UNFCCC in Cancun, Mexico (Cancun COP) in 2010, parties agreed to add language to the final agreement that -135

14) Invites all Parties to enhance action on adaptation under the Cancun Adaptation Framework, taking into account their common but differentiated responsibilities and respective capabilities, and specific national and regional development priorities, objectives and circumstances, by undertaking, inter alia, the following: .... (f) Measures to enhance understanding, coordination and cooperation with regard to climate change induced displacement, migration and planned relocation, where appropriate, at national, regional and international levels.

Solomon and Warner have provided a far more detailed summary of the potential uses of this language, but at least there is now language as part of the UNFCCC process suggesting that countries should coordinate with each other to make climate-change-induced displacement, migration and planned relocation happen as smoothly as possible. In this text, small island nations

1321951 Convention, Article 1(A)(2); see also Ruddick (1997:448).

133 Klein Solomon \& Warner (2013).

134 (ibid.).

135 Cancun Agreement para. 14(f). 
and their governments have been provided with a tool to guide their discussions with countries around the world and seek the aid they will need. It seems clear that early on in this process, discussions will be limited to efforts to promote understanding of the scope of the issue. It is also clear that many of these efforts to coordinate will continue along the current planning trajectory, which includes utility of bilateral and multilateral agreements. ${ }^{136}$ However, this text gives some hope that, through Paragraph 14(f), the UNFCCC can provide a basis for the "operational cooperation" that will be needed to manage the flows of people as sea-level rise becomes much more severe. ${ }^{137}$

Beyond the possibilities listed above, the prospects for displaced communities obtaining protection as they uproot their lives are limited. Perhaps the most straightforward eventuality is that island nations lose their status as nations, and the resulting displaced communities find themselves classified as 'stateless' peoples. Island communities may try to avoid this outcome because of the loss it would mean to community cohesion, even if such a status might provide additional avenues for obtaining support. ${ }^{138}$ Several options for obtaining support would still be available to displaced citizens from these nations, with several national and multi-national programmes available that may provide protections to island nation diaspora. ${ }^{139}$ And with the added benefit of nationhood, threatened island nations may enter into new (or rely more heavily on existing) arrangements with other countries to accommodate their populations, financing such movements through some combination of national assets and rents, and aid from the rest of the world. This article does not address the multitude of options surrounding bilateral and multilateral arrangements in detail, but such options merit thorough consideration.

\section{F. The Possibility for Future Protections}

In the face of what is widely acknowledged to be an incomplete and imperfect set of existing protections for communities facing climate-related displacement, several scholars have proposed new regimes and treaties better

136 Wyman (2013); see F below for a discussion of possible multilateral treaty options.

137 Klein Solomon \& Warner (2013).

1381954 Convention Relating to the Status of Stateless Persons, Article 1.

139 For a summary of such programs see Wyman (2013). 
designed to address the particular needs of climate-displaced persons. These proposals have spawned a debate both among proponents of the various proposed options, and between those calling for a change and those who feel that efforts in this area are best served by securing protections under the existing regime.

Among the proposals for new protection regimes, five in particular stand out as particularly noteworthy: those from Frank Biermann and Ingrid Boas (Biermann-Boas Plan), ${ }^{140}$ Bonnie Docherty and Tyler Giannini (DochertyGiannini Plan), ${ }^{141}$ Dana Falstrom (Falstrom Plan), ${ }^{142}$ David Hodgkinson and his team (Hodgkinson Plan), ${ }^{143}$ and Michel Prieur and his team (Prieur Plan). ${ }^{144}$ Each of these plans contains a particular set of policy choices and implementation methods, and offers different rationales for these choices. Among the elements that differ from treaty to treaty are how they define the class of persons protected by such an agreement, what types of climate displacement events they cover (sudden, gradual, or both), whether they address the needs of internally displaced persons, what level (and type) of coercion they anticipate applying against member states to ensure compliance, and what form the administration of the treaty might take (and whether it would be independent or tied in with an existing international bureaucracy such as the UNFCCC).

Among the most relevant distinctions for the populations of small island nations is the degree to which the various plans purport to address the plight of internally displaced persons. This is because international refugees coming from such islands represent a small fraction of the total number of people expected to be displaced by climate change over the coming centuries. ${ }^{145}$ Treaties granting protections exclusively to internationally displaced persons (which is of course undesirable from the perspective of internally displaced communities), or at least addressing the unique needs of the two groups separately, are more likely to provide the practical level of support such communities will require. Of the five, the Docherty Plan and the Falstrom Plan are the two that cater entirely to displaced persons crossing in-

140 Biermann \& Boas (2007).

141 Docherty \& Giannini (2010).

142 Falstrom (2001).

143 Hodgkinson et al. (2010); see also Hodgkinson \& Young (2013).

144 Prieur (2010); For a more thorough discussion of these five works, as well as others, see Hodgkinson \& Young (2013).

145 Compare Wyman (2013) with Myers (2005). 
ternational borders, omitting entirely the matter of internally displaced persons. ${ }^{146}$ The other three plans are much broader, covering all persons who may be forced from their homes, even when they stay in their home countries, although the Hodgkinson Plan at least draws a distinction between the two groups. ${ }^{147}$

In a similar vein, the Docherty and Hodgkinson Plans limit their applicability to communities displaced as a result of climate change, whereas the other three more generally advocate protections for those displaced as consequence of a variety of environmental events. ${ }^{148}$ Here the distinction may be less important: numerous scientific teams have warned that climate change will also lead to an increase in intense storms that will cause some of the worst incidents of environmental displacement, as well as a change in precipitation patterns that could cause additional flooding or drought events in different parts of the globe. ${ }^{149}$ But all else being equal, it is likely that the more specific treaty (focusing on events at least made more likely by climate change) would be more narrowly tailored, on balance, to the specific needs of island communities.

Another important distinction among the various proposals lies in their approach to addressing the need for migration, between establishing protections for eventual migration channels, and establishing such migration channels in advance of any disasters that would necessitate movement. Here, there is a range of coverage. The Falstrom and Docherty-Giannini Plans focus their proposals heavily on those who are "forced" to leave, owing to "threats to a refugee's survival". ${ }^{150}$ These therefore appear to leave less room for advanced planning before moving becomes absolutely necessary. By contrast, both Hodgkinson and Biermann-Boas contemplate conventions that would include planned relocation and resettlement in advance of expected migration. The Hodgkinson Plan anticipates protections for "prospective migration based on likely consequences of climate change", ${ }^{151}$ and the Biermann-Boas Plan notes that the "need for local populations to leave regions that suffer from increased risk can be foreseen" and such exoduses could be "carried out in planned, voluntary relocation and resettlement pro-

146 Doherty Plan; Falstrom Plan.

147 Hodgkinson \& Young (2013).

148 Docherty Plan; Hodginson Plan.

149 Carr et al. (2013).

150 Falstrom Plan; Docherty-Giannini Plan.

151 Hodgkinson Plan. 
grammes - sometimes over many years and decades - for certain populations as opposed to spontaneous flights". ${ }^{152}$ Finally, the Prieur Plan also appears to provide for advanced resettlement, although this is less clear: his plan covers populations whose "displacement [is] made inevitable by environmental disaster". ${ }^{153}$ This would seem to include situations where displacement is inevitable, although Prieur does not explicitly state this. In the context of threatened nations, such provisions may be critically important: a convention allowing for an island to plan its relocation in advance with the benefit of displaced-persons protections would be significantly more useful than one forcing island communities to wait for a particularly powerful storm before gaining such protections.

As important as the differences among the various proposals are, the similarities indicate a certain degree of consensus on the best course of future action. For instance, all these plans base their laws on, and work to maintain consistency with, existing human rights and humanitarian law. ${ }^{154}$ They establish both norms of protection, and, more prosaically, methods for acquiring humanitarian assistance. And they take great trouble to define a group of people moving who may obtain the benefits of their proposed conventions. ${ }^{155}$ In fact, several of the authors have taken great pains to compare their various proposals, and the general approach among those proposing new agreements has been engagement and cooperation rather than competition. ${ }^{156}$

The number of broad similarities among the various proposals has enabled these academics collectively to counter a contrary line of thinking in the scholarly community, which questions more broadly the merits of seeking to pass any new climate-specific human rights treaty. Several academics (Jane McAdam being among the most prominent) have come out against a new convention focused specifically on climate refugees (or even environmental refugees). ${ }^{157}$ The main arguments against efforts to press for new

152 Biermann-Boas Plan 25.

153 Prieur Plan.

154 Klein Solomon \& Warner (2013).

155 Jane McAdam (2011). See Hodgkinson \& Young (2013).

156 For example, Hodgkinson and Prieur both spoke at the Conference on Threatened Island Nations: Legal Implications of a Changing Climate, held at Columbia Law School, New York, NY, May 23-25, 2011 and expressed their desire to work together to modify their individual agreements. Further, Hodgkinson \& Young (2013) discuss the other major proposals in some detail.

157 See e.g. McAdam (2011). 
rules in the climate arena are (1) that such efforts are likely to be futile, and would ultimately detract from more promising efforts within the existing system; (2) that the definitional problem when establishing special protections for persons displaced by climate (or environmental) factors is too difficult to overcome (how does one define persons displaced by environmental factors as opposed to those displaced as a result of economic or personal circumstances?); (3) that as a consequence of definitional ambiguities that would result, such a system would be vulnerable to gaming by dishonest people looking for a way to circumvent the existing migration system; and (4) that even if a treaty passed and addressed the definitional concerns above, it could not possibly address the full range of issues required to be addressed to prepare for dramatically rising seas in the coming century and beyond. ${ }^{158}$ These critics instead propose that the community continue to use existing international law and principles.

Perhaps the central question dividing commentators on this issue is the feasibility of passing a new convention. It seems clear that, if the international community is extremely unlikely to adopt a new set of rules, then any effort to pass such a set of new rules would ultimately be fruitless. The question of how feasible a new convention might be will ultimately be determined by states and international politics, and is difficult to answer from an academic perspective, although it seems clear that a country unwilling to take on new obligations is likely be unwilling to do so even under a new convention. This critique may be more effective with some proposals than others: for instance, most of the plans envision some form of binding obligations with attached punishments for noncompliance; but the Hodgkinson Plan does not contain any enforcement provisions, instead envisioning itself as a tool countries might use for more effective cooperation. ${ }^{159}$

At the very least though, critics argue that the negotiation and ratification process is likely to take a long time, which carries the risk that protracted and inconclusive negotiations or low numbers of ratifying states following a conclusion may "serve as an excuse for inaction and distract from actual, current needs - which in the case of sinking island [communities] might be so pressing that the [communities] cannot afford to wait for the conclusion of a lengthy process". ${ }^{160}$ Perhaps the most interesting response to this concern comes from those who have urged that the climate change problem

158 McAdam (2011); McAdam \& Saul (2010).

159 Hodgkinson Plan.

160 Klein Solomon \& Warner (2013). 
should be "split ... into different pieces" so that specialised forums can address discrete issues, such as the need to prepare for climate displacement without being distracted by more contentious issues (including liability for climate change and mitigation efforts). ${ }^{161}$ Such a 'building block approach' might enable different elements of climate governance to proceed at different paces, and yield partial results where complete consensus is impossible. ${ }^{162}$ The details of such an arrangement are beyond the scope of this article; but the possibility of such a process would make efforts to call for a new treaty specifically addressing the needs of threatened island communities much more plausible.

The second set of critiques against proposals for new treaties focuses on the difficulty of distinguishing between people displaced by climate (or even environmental) factors, as opposed to social or economic factors. As Jane McAdam, one of the leading voices arguing that efforts to pass a new treaty are misplaced, observes: ${ }^{163}$

Treaty proposals are premised on certain assumptions about climate change and human movement that are not borne out in the empirical studies ... which show that movement is likely to be predominantly internal and/or gradual, rather than in the nature of refugee "flight."

In other words, treaties seeking to identify victims of climate-related events would inevitably be forced to draw difficult and possibly somewhat arbitrary distinctions between environmental refugees and other refugees (and even fortune seekers). This observation bleeds into the third critique, that owing to the distinctions, such systems would be easy to manipulate by certain parties. In responding to such critiques, academics such as Hodgkinson argue that their proposals address the issue of identification through the establishment of complicated "institutional architecture" to address these definitional concerns, as well as through the development of carefully crafted definitions. ${ }^{164}$ Hodgkinson further observes that "complexity of a pursuit does not necessarily render that pursuit any the less worthwhile". ${ }^{165}$ Hodgkinson's observation has some merit: policies often turn on intricate definitional issues, and policymakers are constantly required to draw distinctions based on difficult-to-isolate definitional points. Such policies may leave them-

161 Bodansky (2010).

162 Falkner et al. (2010).

163 McAdam (2011:8).

164 See Hodgkinson \& Young (2013).

165 (ibid.). 
selves open to manipulation, but as with any administrative system, to the extent that newly established climate refugee regimes are properly run, it may be possible to minimise administrative issues.

Finally, several academics have argued that the various proposed conventions cannot single-handedly address the multitude of issues that will need to be resolved. ${ }^{166}$ In this case, there appears to be at least some agreement between the two sides of the issue: as above, the various authors generally anticipate their treaties as building onto existing protection infrastructure, and as Hodgkinson particularly notes, his "convention provides a general framework for CCDP [.....] assistance as one element of a wider international climate change "regime complex"" ${ }^{167}$ However, this response to the critique is perhaps too simple. The full set of plans analysed in this article focus sharply on controlling migration, either as emergencies arise or years in advance of such a need; but they do not concentrate much of their focus on shoring up existing some communities to enable them to stay for as long as possible. This demonstrates a disregard for the political reality in many of these island nations, which is characterised by a determination to adapt infrastructure and prepare for a changing planet. ${ }^{168}$ Michele Klein Solomon and Koko Warner explain this balance as follows: 169

A convention would likely have to choose between a remedial and a preventive approach. Both have their limitations in the context of environmental migration: a purely remedial (post hoc) stance would mean missing a chance to act to avert a worst case scenario; a preventive approach, however, should be careful to avoid suppressing migration at all costs, as doing so may in fact increase the risk of vulnerability and harm.

The major point to remember here is that improvements in infrastructure are important even if an island will eventually become uninhabited, because such improvements can significantly reduce loss of life in the decades before actual evacuation becomes wholly necessary, and can also push back that eventual date. Treaties focused entirely on preparing for migration and protecting migrants may distract policy planners from considering improve-

166 McAdam (2011).

167 Hodgkinson et al. (2010).

168 See e.g. proceedings from the Conference on Threatened Island Nations: Legal Implications of a Changing Climate, held at Columbia Law School, New York, NY, May 23-25 2011.

169 Klein Solomon \& Warner (2013). 
ments in infrastructure, dwellings, agriculture, and other items that could save lives in the interim.

\section{G. Conclusion}

Global climate change is a complex phenomenon, and there are generally few scientific certainties where it comes to predicting future physical impacts. One point on which there is broad scientific consensus, however, is that warming temperatures will cause sea levels to rise around the planet, placing low-lying islands at particular risk of submersion. As a result, island communities face the dire possibility of forced evacuation from their homelands, and a resulting loss of national heritage and community cohesion, over the coming century and beyond.

As many island nations, which today possess full sovereignty, become incapable of sustaining a permanent population owing to sea-level rise, their citizens will no doubt take steps to preserve their identities in whatever way possible. This article explores the host of imperfect options available to these communities. Among the issues that climate-threatened island communities must decide upon are whether they will be able to (1) maintain their nationhood; (2) utilise marine resources as a source of revenue; and (3) rely on existing or possible new human rights protections for their people as they seek to establish new lives in foreign lands. Unfortunately, there are no clear answers on any of these fronts: these questions are important precisely because they are novel, and even if threatened nations exert their full diplomatic weight in support of their citizens it is not clear how successful they will be. As a result, instead of attempting to provide advice to island nations, this article presents a number of possible paths forward for these communities; in the face of such uncertainty, advance preparation and thoughtful planning will be required to avoid serious societal breakdowns on these islands.

The total population of islands that may become uninhabitable in the next century is tiny compared to the full scope of human migration that global climate change will set in motion. But with their low-lying habitats threatened in their entirety by submergence, island populations face potential loss not just of their homes, but of their very identities. As the world prepares for a difficult transition into the future, the plight of these communities should not be forgotten. 


\section{References}

Biermann, Frank \& Ingrid Boas, 2007, Preparing for a Warmer World: Towards a Global Governance System to Protect Climate Refugees, Global Environmental Politics, 10 (1), 60-88.

Bird, Eric C. F. \& John R. V. Prescott, 1989, Rising Global Sea Levels and National Maritime Claims, Marine Policy Reports 177, 177-196.

Blackman, Jeffrey L., 1998, State Successions and Statelessness: The Emerging Right to an Effective Nationality under International Law, Michigan Journal of International Law 19, 1141-1194.

Bodansky, Daniel, 2010, The International Climate Change Regime: The Road From Copenhagen, available at http://belfercenter.ksg.harvard.edu/files/Bodansky-VP-Oct ober-2010-3.pdf, last accessed 19 March 2013.

Bronner, Ethan \& Christine Hauser, 2012, U.N. Assembly, in Blow to U.S., Elevates Status of Palestine, The New York Times, 29 November 2012, available at http://ww w.nytimes.com/2012/11/30/world/middleeast/Palestinian-Authority-United-Nations -Israel.html, last accessed 18 March 2013.

Burkett, Maxine A., 2013, The Nation Ex-Situ, in: Michael B. Gerrard \& Gregory E. Wannier (Eds), Threatened Island Nations: Legal Implications of Rising Seas and a Changing Climate, Cambridge, Cambridge University Press, 89-122.

Carr, Mary-Elena, Madeleine Rubenstein, Alice Graff \& Diego Villarreal, 2013, Sea Level Rise in a Changing Climate: What Do We Know?, in: Michael B. Gerrard \& Gregory E. Wannier (Eds), Threatened Island Nations: Legal Implications of Rising Seas and a Changing Climate, Cambridge, Cambridge University Press, 15-56.

Cooper, Jessica, 1998, Environmental Refugees: Meeting the Requirements of the Refugee Definition, New York University Environmental Law Journal 6, 480-529.

Crawford, James R., 2006, The Creation of States in International Law (Second Edition), Oxford, Oxford University Press.

Darrow, Mac \& Louise Arbour, The Pillar of Glass: Human Rights in the Development Operations of the United Nations, American Hournal of International Law 103, 446501.

Docherty, Bonnie \& Tyler Giannini, 2010, Confronting a Rising Tide: A Proposal for a Convention on Climate Change Refugees, Harvard Environmental Law Review 33, 349-403.

Falkner, Robert, Hannes Stephan \& John Vogler, 2010, International Climate Policy after Copenhagen: Towards a "Building Blocks" Approach, Global Policy 1 (3), 252-262.

Falstrom, Dana Z., 2001, Stemming the Flow of Environmental Displacement: Creating a Conventino to Protect Persons and Preserve the Environment, Colorado Journal of International Environmental Law 1, 1-19, available at http:/www.uio.no/studier/em ner/jus/jus/JUR5530/v 07/undervisningsmateriale/environmental\%20refugees $\% 20 \mathrm{ar}$ ticle.pdf, last accessed 19 March 2013. 
Freestone, David \& Alex G. Oude Elferink, 2005, Flexibility and Innovation in the Law of the Sea: Will the LOS Convention Amendment Procedures Ever Be Used?, in: Oude Elferink, Alex G. (Ed.), Stability and Change in the Law of the Sea: The Role of the LOS Convention, Leiden, Martinus Nijhoff Publishers 169-222.

Gerrard, Michael B. \& Gregory E. Wannier (Eds), Threatened Island Nations: Legal Implications of Rising Seas and a Changing Climate, Cambridge, Cambridge University Press (2013).

Gillespie, Alexander, 2004, Small Island States in the Face of Climate Change: The End of the Line in International Environmental Responsibility, University of California at Los Angeles Journal of Environmental Law and Policy 22 (1), 107-129.

Grote Stoutenburg, Jenny, 2013, When Do States Disappear?: Thresholds of Effective Statehood and the Continued Recognition of "Deterritorialized" Island States, in: Michael B. Gerrard \& Gregory E. Wannier (Eds), Threatened Island Nations: Legal Implications of Rising Seas and a Changing Climate, Cambridge, Cambridge University Press, 57-88.

Hannum, Hurst, 1995-1996, The Status of the Universal Declaration of Human Rights in National and International Law, Georgia Journal of International and Comparative Law 25, 287-397.

Hay, John E., Nobuo Mimura, John Campbell, Solomone Fifita, Kanayathu Koshy, Roger F. McLean, Taito Nakalevu, Patrick Nunn \& Neil de Wet, 2003, Climate Variability and Change and Sea level Rise in the Pacific Islands Region: A Resource Book for Policy and Decision Makers, educators and Other Stakeholders, Japan Ministry of the Environment \& South Pacific Regional Environment Programme, available at http://www.sprep.org/att/IRC/eCOPIES/pacific_region/62.pdf, last accessed 18 March 2013.

Hayashi, Moritaka, 2009, Sea Level Rise and the Law of the Sea: Legal and Policy Options, in: Terashima, Hiroshi (Ed.), Proceedings of the International Symposium on Islands and Oceans, Tokyo, Ocean Policy Research Foundation, 78-90.

Henckaerts, Jean-Marie \& Louise Doswald-Beck, 2005, Customary International Humanitarian Law, Cambridge, Cambridge University Press.

Hodgkinson, David, Tess Burton, Heather Anderson \& Lucy Young, 2010, The Hour When the Ship Comes, available at http://www.ccdpconvention.com/documents/Ho ur_When_Ship_Comes_In.pdf, last accessed 19 March 2013.

Hodgkinson, David \& Lucy Young, 2013, "In the Face of Looming Catastrophe": A Convention for Climate-Change-Displaced Persons, in: Threatened Island Nations: Legal Implications of Rising Seas and a Changing Climate, Cambridge, Cambridge University Press, 299-336.

Holmes, Stephanie, 2008, Breaking the Ice: Emerging Legal Issues in Arctic Sovereignty, Chicago Journal of International Law 9, 323-352.

IEA/International Energy Agency, 2012, $\mathrm{CO}_{2}$ Emissions From Fuel Combustion: Highlights, Paris, IEA, available at http://www.iea.org/publications/freepublications/publ ication/CO2emissionfromfuelcombustionHIGHLIGHTS.pdf, last accessed $18 \mathrm{March}$ 2013. 
IPCC/Intergovernmental Panel on Climate Change, 2007, Summary for Policaymakers, The Physical Science Basis, Contribution of Working Group I to the Fourth Assessment Report of the Intergovernmental Panel on Climate Change, available at http://w ww.ipcc.ch/publications_and_data/publications_ipcc_fourth_assessment_report_wg 1_report_the_physical_science_basis.htm, last accessed 18 March 2013.

Jesus, José Luis 2003, Rocks, New-Born Islands, Sea Level Rise and Maritime Space, in: Frowein, Jochen A., Klaus Scharioth, Ingo Winkelmann, Rüdiger Wolfrum (Eds), Verhandeln für den Frieden, Negotiating for Peace: Liber Amicorum Tono Eitel, Berlin, Springer, 579-604.

Kapoor, Deepak C. \& Adam Kerr, 1986, A Guide to Maritime Boundary Delimitation, Toronto, Carswell.

Klein Solomon, Michele \& Koko Warner, 2013, Protection of Persons Displacesd as a Result of Climate change: Existing Tools and Emergine Frameworks, in: Threatened Island Nations: Legal Implications of Rising Seas and a Changing Climate, Cambridge, Cambridge University Press, 243-298.

Knox, John H., 2009, Linking Human Rights and Climate Change at the United Nations, Harvard Environmental Law Review 33, 477-498.

Kolmannskog, Vikram, 2009, Climate Change, Disaster, Displacement and Migration: Initial Evidence from Africa, New Issues in Refugee Research, Research Paper No. 180, United Nations High Commissioner for Refugees, The United Nations Refugee Agency, Policy Development and Evaluation Service, available at http://www.unher .org/4b18e3599.html, last accessed 18 March 2013.

Lavalle, Robert, 2004, Not Quite a Sure Thing: The Maritime Areas of Rocks and LowTide Elevations under the UN Law of the Sea Convention, The International Journal of Marine and Coastal Law 19, 43-69.

Leighton, Michelle, 2010, Climate Change and Migration: Key Issues for Legal Protection of Migrants and Displaced Persons, The German Marshall Fund of the United States, Study Team on Climate Induced Migration, available at http://www.ehs.unu. edu/file/get/7102, last accessed 19 March 2013.

Lopez, Aurelie, 2007, The Protection of Environmentally-Displaced Persons in International Law, Environmental Law 37 (2), 365-409.

McAdam, Jane, 2010, 'Disappearing States', Statelessness and the Boundaries of International Law, in: McAdam, Jane (Ed.), Climate Change and Displacement: Multidisciplinary Perspectives, Oxford, Hart Publishing, 105-130.

McAdam, Jane, 2011, Swimming against the Tide: Why a Climate Change Displacement Treaty Is Not the Answer, International Journal of Refugee Law 23, 2-27.

McAdam, Jane \& Ben Saul, 2010, Displacement with Dignity: International Law and Policy Responses to Climate Change, Migration and Security in Bangladesh, University of New South Wales Faculty of Law Research Series, Paper No. 63, available at http://papers.ssrn.com/sol3/papers.cfm?abstract_id=1701486, last accessed 19 March 2013.

McInerney-Lankford, Siobhan, 2013, Human Rights and Climate Change: Reflections on International Legal Issues and Potential Policy Relevance, in: Threatened Island Nations: Legal Implications of Rising Seas and a Changing Climate, Cambridge, Cambridge University Press, 195-242. 
Meehl, Gerald A., Thomas F. Stocker, William D. Collins, Pierre Friedlingstein, Amadou T. Gaye, Jonathan M. Gregory, Akio Kitoh, Reto Knutti, James M. Murphy, Akira Noda, Sarah C.B. Raper, Ian G. Watterson, Andrew J. Weaver \& Zong-Ci Zhao, 2007, Global Climate Projections, in: Solomon, Susan, Dahe Qin, Martin Manning, Zhenlin Chen, Melinda Marquis, Kristen B. Averyt, Melinda M.B. Tignor \& Henry L. Miller (Eds), Climate Change 2007 : The Physical Science Basis. Contribution of Working Group I to the Fourth Assessment Report of the Intergovernmental Panel on Climate Change, Cambridge, Cambridge University Press, 747-845.

Menefee, Samuel, 1991, Half Seas Over: The Impact of Sea Level Rise on International Law and Policy, University of California at Los Angeles Journal of Environmental Law and Policy 9, 175-218.

Milne, Glenn A., W. Roland Gehrels, Chris W. Hughes \& Mark E. Tamisiea, 2009, Identifying the Causes of Sea Level Change, Nature Geoscience 2, 471-478.

Mimura, Nobuo L., Leonard Nurse, Roger McLean, John Agard, Lino Briguglio, Penehuro Lefale, Rolph Payet \& Graham Sem, 2007, Small Islands, in: Parry, Martin L., Osvaldo F. Canziani, Jean Palutikof, Paul J. Van der Linden \& Clair E. Hanson (Eds), Climate Change 2007: Impacts, Adaptation and Vulnerability. Contribution of Working Group II to the Fourth Assessment Report of the Intergovernmental Panel on Climate Change, Cambridge, Cambridge University Press, 687-716.

Mohamed, Ali, 2012, Why not recognize independent Somaliland?, Global Post, 22 May 2012, available at http:/www.globalpost.com/dispatches/globalpost-blogs/comment ary/somaliland-independence-somalia-united-nations-piracy, last accessed $18 \mathrm{March}$ 2013.

Myers, Norman, 2005, Environmental Refugees: An Emergent Security Issue, 13th Economic Forum, 23-27 May 2005, Prague, available at http://www.osce.org/eea/14851, last accessed 18 March 2013.

Nurse, Leonard A., Graham Sem, John E. Hay, Avelino G. Suarez, Poh Poh Wong, Lino Briguglio \& Sachooda Ragoonaden, 2001, Small Island States, in: Payet, Rolph \& Simad Saeed (Eds), Climate Change 2007: Impacts, Adaptation and Vulnerability. Contribution of Working Group II to the Third Assessment Report of the Intergovernmental Panel on Climate Change, Cambridge, Cambridge University Press, 843 875.

Perritt, Henry H. Jr., 2003, Structures and Standards for Political Trusteeship, University of California, Los Angeles, International Law and Foreign Affairs 8, 385-472.

Pfeffer, W. Tad, Joel T. Harper \& Shad O’Neel, 2008, Kinematic Constraints on Glacier Contributions to 21st-Century Sea Level Rise, Science 321, 1340, 1343.

Pollard, John F., 2005, Money and the Rise of the Modern Papacy: Financing the Vatican, 1850-1950, Cambridge, Cambridge University Press.

Prieur, Michel, 2008, Draft Convention on the International Status of EnvironmentallyDisplaced Persons, Francophone European Environmental Law Review 4, $381 \mathrm{ff}$.

Rayfuse, Rosemary, 2009, (W)hither Tuvalu? International Law and Disappearing States, in University of New South Wales Faculty of Law Research Series 9, 1-13, available at http://papers.ssrn.com/sol3/papers.cfm?abstract_id=1412028, last accessed 18 March 2013. 
Rayfuse, Rosemary, 2013, Sea Level Rise and Maritime Zones: Preserving the Maritime Entitlements of "Disappearing" States, in: Threatened Island Nations: Legal Implications of Rising Seas and a Changing Climate, Cambridge, Cambridge University Press, 167-194.

Ruddick, Elizabeth E., 1997, The Continuing Constraint of Sovereignty: International Law, International Protection, and the Internally Displaced, Boston University Law Review 77, 429-482.

Schofield, Clive \& David Freestone, 2013, Options to Protect Coastlines and Secure Maritime Jurisdictional Claims in the Face of Global Sea Level Rise, in: Michael B. Gerrard \& Gregory E. Wannier (Eds), Threatened Island Nations: Legal Implications of Rising Seas and a Changing Climate, Cambridge, Cambridge University Press, 141-166.

Song, Yann-huei, 2009, Okinotorishima: A "Rock" or an "Island"? Recent Maritime Boundary Controversy between Japan and Taiwan/China, in: Hong, Seoung-Yong \& Jon M. Van Dyke (Eds), Maritime Boundary Disputes, Settlement Processes, and the Law of the Sea, The Hague, Martinus Nijhoff Publishers, 145-176.

Soons, Alfred, 1990, The Effects of a Rising Sea Level on Maritime Limits and Boundaries, Netherlands International Law Review 37, 207-233.

Symmons, Clive R., 1995, Some Problems Relating to the Definition of "Insular Formations" in International Law: Islands and Low-Tide Elevations, International Boundaries Research Unit Maritime Briefing 1 (5), 1-39.

The Washington Times, 2009, Climate Refugees in Pacific Flee Rising Sea, The Wasington Times, 19 April 2009, available at http:/www.washingtontimes.com/news/20 09/apr/19/rising-sea-levels-in-pacific-create-wave-of-migran, last accessed $18 \mathrm{March}$ 2013.

United Nations High Commissioner for Refugees, 2007, Protection of Persons Involved in Migration: Note on IOM's Role, International Migration Law and Legal Affairs Department, June 2007, available at http://www.unhcr.org/4bf644779.html, last accessed 19 March 2013.

United Nations High Commissioner for Refugees, 2009, Climate Change, Natural Disasters and Human Displacement: A UNHCR Perspective, 14 August 2009, available at http://www.unhcr.org/refworld/docid/4a8e4f8b2.html, last accessed 19 March 2013.

US Department of State, 2012, Holy See Factsheet, 14 December 2012, available at http:// www.state.gov/r/pa/ei/bgn/3819.htm, last accessed 18 March 2013.

Vainerere, Tangata, 2009, Climate Change Refugees Return to Bougainville Atolls, PACNEWS, 22 July 2009, available at http://www.pina.com.fj/index.php?p=pacnew $\mathrm{s} \& \mathrm{~m}=\mathrm{read} \& \mathrm{o}=13753591344 \mathrm{a} 6693 \mathrm{dcc} 52387 \mathrm{de} 688 \mathrm{~d} \&$ PHPSESSID $=57 \mathrm{ce} 2 \mathrm{c} 307 \mathrm{dc} 9 \mathrm{a}$ 0c197f0c0118452d4ac, last accessed 18 March 2013.

Van Dyke, Jon M. \& Robert A. Brooks, 1983, Uninhabited Islands: Their Impact on the Ownership of the Oceans' Resources, Ocean Development and International Law 12 265-300.

Vermeer, Martin \& Stefan Rahmstorf, 2009, Global Sea Level Linked to Global Temperature, Proceedings of the National Academy of Sciences 106, 21527-21532. 
Wannier, Gregory E. \& Michael B. Gerrard, 2013, Overview, in: Michael B. Gerrard \& Gregory E. Wannier (Eds), Threatened Island Nations: Legal Implications of Rising Seas and a Changing Climate, Cambridge, Cambridge University Press, 3-14.

Williams, Angela, 2008, Turning the Tide: Recognizing Climate Change Refugees in International Law, Law \& Policy 30, 502-529.

Wyman, Katrina, 2013, The National Immigration Policy Option: Limits and Potential, in: Michael B. Gerrard \& Gregory E. Wannier (Eds), Threatened Island Nations: Legal Implications of Rising Seas and a Changing Climate, Cambridge, Cambridge University Press, 337-368. 
